by the spectroscope, the spectroheliograph, and the spectrohelioscope, as well as the minute Zeeman effects that reveal the general magnetic field of the sun. Various geophysical phenomena, including magnetic storms, the aurora, and those associated with the transmission of radio messages, are also involved. Indeed, we may reasonably hope that some of the most fundamental questions of physics, chemistry, and astronomy may be illuminated by an intensive study, both observational and theoretical, of the problems of solar magnetism."
S. Chapmax.

\title{
THE CHINESE PEASANT
}

\section{Peasant Life in China}

A Ficld Study of Country Life in the Yangtze Valley. By Dr. Hsiao.'Tung Fei. Pp. xxvi $+300+$ 14 plates. (London: George Routledge and Sons, Ltd., 1939.) 12s. $6 d$. net.

"I VENTURE to foretell," says Prof. Malinowski in opening his interesting preface to this book, 'that 'Peasant Life in China' by Dr. Hsiao.'Tung Fei will be counted as a landmark in the development of anthropological field-work and theory." Later he quotes Sir Denison Ross in a statement in which he defines the position of this work in scientific literature and says "I regard this treatise as quite exceptional. I know of no other work which describes at first hand and with intimate understanding the full story of life in a Chinese village community. We have had works dealing with statistics, economic studies and novels full of local colour-but in no book have I found the answer to every enquiry, which the curious stranger might make". Commendation could not well go further. 'These authorities, each selecting for mention a quality and aspect of this piece of field-work, which offers to him a special appeal, emphasizes its two-fold interest for the reader. On one side the book is a first-rate study of social conditions, which though drawn from a limited area, may be taken as applying with local modifications to a preponderance of the population of China immediately before present Japanese aggression; on the other side it is a practical demonstration of the contribution to be made by anthropological studies in the field towards a planned approach to the solution of the problems, political, social and administrative, which arise from cultural contacts, when Western civilization impinges on other, and in a material sense, less advanced forms of civilization.

Dr. Fei has taken as the scene of his operations Kaisienkung, a village south of Lake Tai in the Yangtze plain in eastern China. The country is a network of canals and waterways, communications being mainly by boat. 'The density of population reaches the remarkable figure of 1,980 per square mile, this calculation, howerer, being based on land surface only, whereas the gross density of the whole province (Kiangau) is about $\$ 96$ per square mile. The main industry is agriculture (rice cultivation) in a system in which the unit of social and economic organization is the expanded family. The returns from rice cultivation, over and above family subsistence requirements, were not adequate to meet family expenditure. They were supplemented by the production of silk as a domestic industry. The village, in fact, was in the centre of the silk-producing area of China. Unfortunately, the fall in world prices of silk has brought disaster to the industry, and the district, like many others, is face to face with the great agrarian problem of China, namely that the cultivation of the land, unsupplemented by other resources, will not support the peasant population.

Dr. Fei reviews in detail, "microscopically" as he puts it, the traditional social and economic system of this village as a working organism, and indicates the changes which have been forced upon it by disintegrating factors, both externalworld economic and social conditions-and internal, due to efforts to ameliorate conditions within the village itself. Of these the most important is the endeavour to raise the standard of silk production and the institution of a village silk factory. Of the changes in custom due to the economic situation, the most striking is the curtailment, or complete cessation of all ceremonial and festive occasions over a period now of ten years duration. One result, for example, is not only the postponement of marriage to a later age, but also a modification of the character of the marriage system itself on the ground of the expense involved in the customary marriage ritual. The introduction of a co-operative factory and wages, which were previously unknown, have had a number of social repercussions, but not the least serious, both in the silk industry and in agriculture, where laboursaving methods of cultivation have been introduced, has been the creation of a class of unemployed labour, especially among the female population.

The village described by Dr. Fei has now been overwhelmed by the Japanese advance; but the author is nevertheless confident that China, as ever before, will eventually rise superior to her trials. 